\title{
Aa@
}

Autobiografia nr 2 (13) 2019 s. 43-46

ISSN 2353-8694

DOI: 10.18276/au.2019.2.13-05

TEORIE

SÁNDOR FERENCZI

\section{Homosexualitas Feminina}

Róza K. alias Róbert K., czterdziestoletnia i niezamężna służąca - której portret zamieszczam obok - jest jednym z tych niefortunnych stworzeń, których wrodzone chorobliwe skłonności powodują niepohamowany pociąg do osób tej samej płci, podczas gdy naturalne, to jest heteroseksualne, zaspokojenie popędu płciowego nie interesuje ich, a nierzadko powoduje wstręt. Tego typu przypadki nie są wcale odosobnione. Wyrastająca jak grzyby po deszczu literatura „naukowa” poświęcona perwersjom seksualnym, która jej autorom i wydawcom dostarcza pokaźnych zysków, zadbała już o to, by lekarze byli rozeznani w każdym szczególe tego działu psychopatologii nieporównywanie lepiej niż w innych, o wiele bardziej znaczących obszarach nauk medycznych. To, że poświęcam temu spostrzeżeniu kilka słów, czynię tylko dlatego, iż niektóre z tych publikacji aż się proszą o skomentowanie.

Biografia Rózy K. jest istną odyseją. Z uwagi na niespokojną naturę, która cechuje ją od urodzenia, a nade wszystko przez nieżyczliwość innych osób kobieta nigdzie nie mogła znaleźć miejsca dłuższego pobytu. Rodzina nie chciała o niej słyszeć, obcy ludzie ją wyśmiewali, nie dawali zatrudnienia, a nawet zdarzył się ktoś, kto w nikczemny sposób wykorzystał jej chorobliwe skłonności i szantażem wymusił jej oszczędności. Najwięcej kłopotów przysparzała Rózie K. policja. W Wiedniu i w Peszcie trafiła do więzienia, gdyż nosiła męskie ubrania. W Esztergomie z kolei, mimo że miała na sobie damski strój, została aresztowana za to, iż wyglądała na przebranego mężczyznę. Wreszcie komenda główna policji w Budapeszcie zezwoliła jej na chodzenie w męskim ubraniu, gdyż w ten sposób najmniej bulwersowała swym wyglądem. Przyzwolenie sporządzono na piśmie, co przyniosło Rózie K. prawdopodobnie największą radość w jej życiu.

W krótkiej autobiografii, którą spisała na moją prośbę, mimo skromnego wykształcenia w zaskakująco czytelny i nienagannie logiczny sposób przedstawiła koleje swojego losu. Róza K. ma fenomenalną pamięć. Jej upodobania muzyczne budzą podziw i choć nie miała możliwości pobierać nauki gry na pianinie czy śpiewu, to za wyżebraną kwotę pięćdziesięciu 
forintów sprawiła sobie katarynkę. Jej słuch muzyczny jest rzeczywiście ponadprzeciętny. Tego typu uzdolnienia towarzyszą perwersjom seksualnym szczególnie często. Już w okresie adolescencji Róza K. lubiła spędzać czas wyłącznie z dziewczętami, co zresztą nie uszło uwadze jej rodziców. Na zabawach cieszyło ją jedynie, kiedy mogła tańczyć z przyjaciółkami. Kobiece robótki ręczne i prace domowe nigdy nie były jej pasją, swój czas wolała poświęcać trudniejszym, bardziej męskim zajęciom. Jej chód jest ciężki, dynamiczny, co w żeńskim ubraniu przykuwa uwagę otoczenia.

Bezduszność rodziców sprawiła, że opuściła dom rodzinny, a z powodu włóczenia się po Wiedniu została przymusowo odesłana do Budapesztu. Stamtąd co jakiś czas jeździła do rodzinnej miejscowości, a nawet przez prawie dwa lata pracowała tam jako kelnerka w małej gospodzie. W miejscu pracy rozegrała się zresztą jedyna prawdziwa historia miłosna Rózy K., o której do dziś wspomina z bólem. Jej sympatią była młoda kasjerka, która - najwyraźniej kierowana chciwością - przyjmowała zaloty „Róberta”. Kobiety nawet wspólnie zamieszkały. Co oczywiste, ich przypominająca małżeństwo relacja była prawdopodobnie platoniczna, nie dziwi zatem, że po kilku miesiącach nieszczęsna R.K. odkryła, że kochanka zdradza ją haniebnie, w dodatku z mężczyzną. W ten sposób osobliwy liaison dobiegł końca.

Po ponownym przymusowym wydaleniu do Pesztu tamtejsze władze umieściły R.K. w przytułku dla ubogich, ale niekończące się szyderstwa, na jakie była wystawiona ze strony współmieszkańców, wzniecały jej niepokój tak bardzo, że wkrótce trafiła pod nieustanną obserwację, a później została odesłana do państwowej placówki opieki psychiatrycznej. Po kilku miesiącach spędzonych w szpitalu kobieta ponownie rozpoczęła - trwającą do dziś - nieustanną tułaczkę, której kolejne przystanki wyznaczają schronisko dla biednych, więzienie, areszt dla włóczęgów, zakład psychiatryczny.

W odniesieniu do fizycznej seksualności R.K. nie można zaobserwować żadnych nieprawidłowości. Zarówno zewnętrzne, jak i wewnętrzne narządy płciowe są prawidłowo rozwiniętymi kobiecymi gruczołami rozrodczymi. R.K. mówi sopranem, jej krtań jest mała, piersi nieznacznie atroficzne, rozmiar miednicy zasadniczo kobiecy. Gestykulacja i chód są raczej męskie, dłonie i stopy duże, rysy twarzy i profil wyraziste. Ciało pozbawione jest zbędnego czy nadmiernego owłosienia.

Jej seksualność psychiczna - jak już wspominałem - objawia się jedynie w stosunku do osób tej samej płci. Zdarzało się, łącznie około dziesięciu razy, że R.K. miewała kontakty cielesne również z mężczyznami, dochodziło do nich jednak wyłącznie z powodów finansowych. Podczas pełnego stosunku heteroseksualnego nie odczuwała żadnego podniecenia. „Ich habe eben nur für Damen Interesse" ${ }^{1}$ - jak podaje w swoim życiorysie. Jej zdolności umysłowe

1 „Interesują mnie tylko panie” (niem.). 
przewyższają kompetencje kobiet pochodzących z podobnych warstw społecznych; potrafi doskonale liczyć w myślach, ma niezwykle rozwiniętą pamięć, a rozeznanie w pojęciach związanych z prawem i moralnością jest u niej całkiem zadowalające. Jedynie nastrój R.K. jest bardzo niestabilny, ze skłonnościami do sentymentalizmu i depresji.

Spośród tak zwanych oznak degeneracji ciała - czy też, innymi słowy, wrodzonych nieprawidłowości rozwojowych - na plan pierwszy wysuwa się gotycko wyżłobione podniebienie przednie, nadmiernie wysunięta żuchwa (prognathia), zbyt duże uzębienie w stosunku do rozmiaru szczęki oraz dwa symetrycznie ulokowane, plackowate odbarwienia skóry poniżej żeber. Twarz jest w znacznej mierze szpetna, co więcej, odstręczająca. Taki poziom brzydoty pozwala mówić już o zwyrodnieniu, albowiem wrażenie nim powodowane jest niczym innym jak estetycznym oddziaływaniem nieprawidłowości, na które składają się liczne szczegóły.

Omawiając niniejszy przypadek, należy się pochylić szczególnie nad dwiema kwestiami. Po pierwsze, gdzie powinno się ulokować taką jednostkę? Biorąc pod uwagę ekscentryczne zachowanie, brak siły do walki z przeciwnościami losu oraz chwiejność emocjonalną powodującą nieobliczalność i kapryśność, trudno jej znaleźć swoje miejsce w społeczeństwie, a równocześnie otrzymać odpowiednie wsparcie i opiekę. Jednak ani więzienie, ani zakład psychiatryczny również nie są dla niej właściwe. Najrozsądniejszym rozwiązaniem wydaje się, by osobę, którą można określić mianem débile i déséquilibré, umieścić w przytułku dla ubogich, gdzie mogłaby korzystać z dość szerokiej swobody, a nawet podjąć pracę, będąc równocześnie mniej narażoną na złą wolę i upokorzenie ze strony innych ludzi.

Drugą kwestię, mianowicie to, jak powstrzymać takie i im podobne osoby przed posiadaniem potomstwa, a więc nie dopuścić ich do udziału w zachowaniu gatunku, wydaje się rozwiązała już sama natura. Doświadczenie pokazuje, że zdegenerowane jednostki są tym mniej zdolne do reprodukcji, im poważniejsze są u nich oznaki fizjologicznego i psychicznego zwyrodnienia. Na przykład idioci - z rzadkimi wyjątkami - umierają bezpotomnie. Z tego punktu widzenia perwersje seksualne, podobne do tych opisanych w niniejszym artykule, są dla społeczeństwa całkiem korzystne: cielesne i duchowe oznaki zwyrodnienia uniemożliwiają takim osobnikom posiadanie progenitury.

Każda odmienność seksualna nie mieści się w normie tylko dlatego, że odbiega od zachowań seksualnych, które przyczyniają się do rozmnażania, o homoseksualizmie natomiast decyduje ten typ kontaktów intymnych, które są najmniej przydatne do utrzymania gatunku. 
Jest więc homoseksualizm - u zdegenerowanych jednostek - nie całkiem zbędną rzeczą przyczynia się do udoskonalania przyszłych pokoleń.

Wreszcie, to chyba nie przypadek, że właśnie zwyrodniałe osobniki są najskłonniejsze do prowadzenia dewiacyjnego życia płciowego. Niewykluczone zarazem, że tkwi w tym swoista teologia natury, czy też - jak kto woli - „automatyczny mechanizm regulujący”.

Survival of the fittest wiąże się nie tylko ze zdolnością służącą u tr z y ma n i u g a t u n ku, lecz także odgrywa rolę w d o b or ze płci. Całkowicie i prawidłowo rozwinięty reprezentant gatunku odczuwa większy pociąg seksualny do przedstawicieli płci przeciwnej, co pomnaża jego szanse na posiadanie potomstwa. Inaczej jest z osobnikami zdegenerowanymi, szpetnymi, które są wykluczone z udziału w tworzeniu przyszłych generacji - o ile oczywiście w grę nie wchodzą inne, niekoniecznie naturalne motywacje, jak choćby interes finansowy. Biorąc więc pod uwagę różne okoliczności, wykluczenie ze względu na płeć nie zawsze daje w tym zakresie całkowitą gwarancję. Zajmując się niegdyś leczeniem prostytutek, miałem okazję się przekonać, że ani brak jednego oka czy nogi, ani skrzywienie kręgosłupa, ani też podeszły wiek czy szpetota nie stanowiły przeszkody, by ktoś nieustannie oraz z powodzeniem - czego dowodziły częste infekcje - trudnił się tym fachem.

Użyteczne i potrzebne jest zatem, że to sama natura troszczy się o selekcję jednostek zwyrodniałych i nie powierza tego zadania ludziom niegodnym zaufania. 